\title{
43 de Abril ou: o drama ridículo de Aksenti Ivanovitch
}

\author{
FÁ B I 0 HERRMAN N
}

Justamente por ser uma sátira social e uma comédia de costumes, muito mais do que um conto psicológico, o “Diário de um Louco", de Gógol(1), situa, com admirável perspicácia, a distância que medeia entre nós e a loucura. A literatura intencionalmente psicológica tende a singularizar demais sua personagem, trata-a como a um ser excepcional, por quem se deve sentir compaixão ou desgosto; tenta compreendê-la, mas, não raro, reduz sua interioridade a uma pequena engrenagem de motivos claros; explicando-a cabalmente, inventa um simulacro de gente. A loucura não é mero assunto pessoal, pois impregna identicamente e num só movimento a vida social, tanto quanto a do indivíduo, posto que, naquela posição, não se deixe ver facilmente; desse modo, extremo cuidado se requer para a observar: podemos ser afetados muito cedo pelo caldo comum em que somos todos cozidos e afastarmo-nos de sua perigosa interioridade, ou não o ser de todo. A interioridade do desvario, sua lógica de concepção, é complexa e insondável, o lado de fora, as imagens que produz, é que se escancaram; daí se deve começar. O conto de Gógol não tenta explicar o lado de dentro de seu doido herói, mas por seus olhos o mundo em que vive mostra sua desrazão, precisamente por isso ele é o louco da história e ninguém pode duvidar do fato; assim, de início, o leitor não está lá nem aqui, não se identifica com a medíocre sociedade retratada, nem se identifica com o miserável conselheiro-titular, que um delírio transforma em Fernando VIII, rei de Espanha: a esse título, posiciona-nos exemplarmente. A habilidade do autor esmera-se em prevenir qualquer deslize de simpatia exagerada ou de prévia condenação que nos pudesse tirar da neutra observação do drama. Seu estilo conciso acompanha, do começo ao fim, a evolução da sandice do protagonista, que registra, em seu Diário, os passos de uma "aventura insólita", sem nunca se desviar do essencial. Uma peripécia, somente, pareceria deslocada: é quando, no registro de 8 de novembro, Aksenti declara ter assistido a "uma espécie de vaudeville"'. Isto mesmo, porém, cumpre um papel; não é toda a história uma espécie de vaudeville, em que a exterioridade e distância com respeito à personagem central reforça nossa posição de observadores observados pela loucura, sem com ela nos comprometer?

Sua loucura não poderia ser mais banal. Funcionário modesto, apesar do título altissonante de "conselheiro-titular" - nono grau da estrutura burocrática russa, que comparte, por exemplo, com Akaki Akakievitch, a desvalida e também cacofônica personagem de $\mathrm{O}$ Capote -, Aksenti Ivanovitch Poprichin é presa de um amor impossível e silencioso pela filha do diretor da repartição pública em que trabalha; sabendo-a noiva de um fidalgo, acaba por enlouquecer de megalomania. Haverá seqüência mais convencional? Dificilmente, porque o "Diário de um Louco" é, antes de mais nada, um estudo acerca da convenção da loucura pessoal e social.

A começar pelo título, todo o suspense é eliminado de antemão. Sabemos que estamos a acompanhar as lucubrações de um delirante - o louco convencional parece sempre ser um delirante -, de seu próprio ponto de vista. Participamos do drama pelo lado de dentro, enxergando pelos olhos do ator principal; no entanto, isto mesmo nos tranqüiliza, distingue e outorga certa distância inicial, pois o Diário é muito bem escrito,
FÁBIO HERRMANN é psicanalista e autor, entre outros livros, de Andaimes do Real - uma Revisáo Critica do Método Psicanaltico (Editora E.P.U.), O que é a Psicanálise (Editora Brasiliense) e $A$ Clínica Psicanaltica - A Arte da Interpretação (Editora Brasiliense).

- Este texto foi publicado originalmente no "Suplemento Cultural" de O Estado de S. Paulo em janeiro de 1983.

\footnotetext{
1 Ediçăo utilizada: Nicolai Gogol, "Diário de um Louco", in Aurélio Buarque de Holanda Ferreira e Paulo Rónai, Mar de Historias, Antologia do conto Mundial, $3^{\circ}$ vol.. "Romantismo", cedido de nota introdutoria cedido de nota introdutoria sobre autor, pp. 98 e segs. Também, Diary of a Madman and other Stories, tradução e introduçăo de Ronald Wilks, Penguin Classics.
} 
obedecendo a uma lógica impecável, sem traços da distorção intrínseca ao pensamento psicótico. O Diário é o conto, e o texto é o de Gógol, não o paralogismo monumental do Finnegans Wake. Isto é, assistimos tão-somente à reconstituição normalizada de uma experiência absurda que, como tal, se esconde inteiramente, não nos ameaçando de contágio. Dentro o bastante para que haja drama, pois são vivos os fatos; mas cegos à lógica produtora das emoções que veicula, distantes da história prévia de Aksenti, que é só o pequeno funcionário infeliz; alheios a seus sentimentos e dores mais comuns, ao tempo em que não era louco ainda, não estamos tentados a simpatizar nem a antipatizar com ele, que, levemente abaixo de ser humano como nós, vive um drama que nos parece ridículo, com toda a razão.

Ridículo, em essência, é o estado em que o mais interior do homem, a estrutura geradora de seus pensamentos, afetos e ações, está exposto na superfície do comportamento, em que o íntimo é exterior. O indivíduo que traz seus motivos à vista de todos perde algo da condição de sujeito, objetiva-se de mau jeito, transformando-se numa espécie de marionete, cujos barbantes de controle estão soltos por aí, arrastados pelo chão, para qualquer transeunte puxar. Essa exposição indiscriminada engendra a comédia, por oposição ao drama, em que o comportamento manifesto é apenas a soleira da porta de um quarto escuro, ou melhor, a beira do precipício insondável da vida interior. O protagonista do drama tem história e faz história, há espessura temporal em cada palavra sua. Já a comédia burlesca é por natureza atemporal e totalmente extrovertida. Ora, Gógol desafia-nos com uma comédia dramática, em que o tempo e a intimidade estão presentes, sob a forma do Diário, conquanto não nos permita mergulhar no tempo interior $\mathrm{e}$ histórico da vida de Aksenti, tanto pela amputação dos antecedentes da ação, quanto pela radical evisceração da personagem, que diz ou escreve tudo o que pensa, sendo ainda mais explícita quando pretende calar algum pensamento impróprio ("psiu..."), que, por isso mesmo, resulta perfeitamente obvio para o leitor. Afinal, para isso serve um diário, para tudo confessar, sem que ninguém fique sabendo; um diário feito carta aberta é o mesmo que um delírio, mostra tudo e desconhece sua lógica profunda: esta é a justa posição do ridículo.

Didaticamente, seu drama divide-se em três partes: um preâmbulo, em outubro, uma ação, em novembro, e a revelação, cujo limiar está datado de dezembro, mas que se precipita pelo tempo da loucura afora.

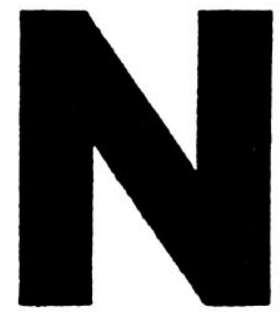

as anotações de 3 e de 4 de outubro, o Diário registra uma aventura e uma paixão. No dia 3, o louco já o era. Os sinais premonitórios, ficamos sabendo, são uma desconformidade com sua função: embaralha os escritos, põe "minúsculas no título", não data os documentos, agita-se sem razão. O funcionário, ser da complicada e inoperante burocracia russa do século XIX, só alcança reter sua sanidade - Gógol devia sabê-lo bem, por experiência pessoal -, pela via da mais absoluta integração com seu cargo, de meticulosa disciplina de identificação com os rituais da inutilidade oficial. Por conseguinte, não nos assombra de todo que Ivanovitch, ao topar ocasionalmente com a filha do diretor da repartição, que sai às compras com sua cadelinha Medji, surpreenda uma animada conversa entre esta última e outra colega canina. A aventura é "insólita", mas não de todo inesperada, em quem tem "ouvido e visto coisas que nunca ninguém ouviu nem viu". Outro sinal de sua desconformidade com a condição de pequeno funcionário lê-se no dia seguinte. Está apaixonado por Sophie, a dona da falante cadela, divinamente inalcançável filha do diretor. Este personagem "não pode ser comparado aos outros mortais. É um homem de Estado."

A essa altura, já estamos em contato com as imagens fundamentais de seu delírio. $\mathrm{O}$ amor calado (cada vez que uma declaração mais direta de interesse erótico ameaça escorregar para as páginas do Diário, ele silencia a indiscrição com um “psiu..."), a gran- 


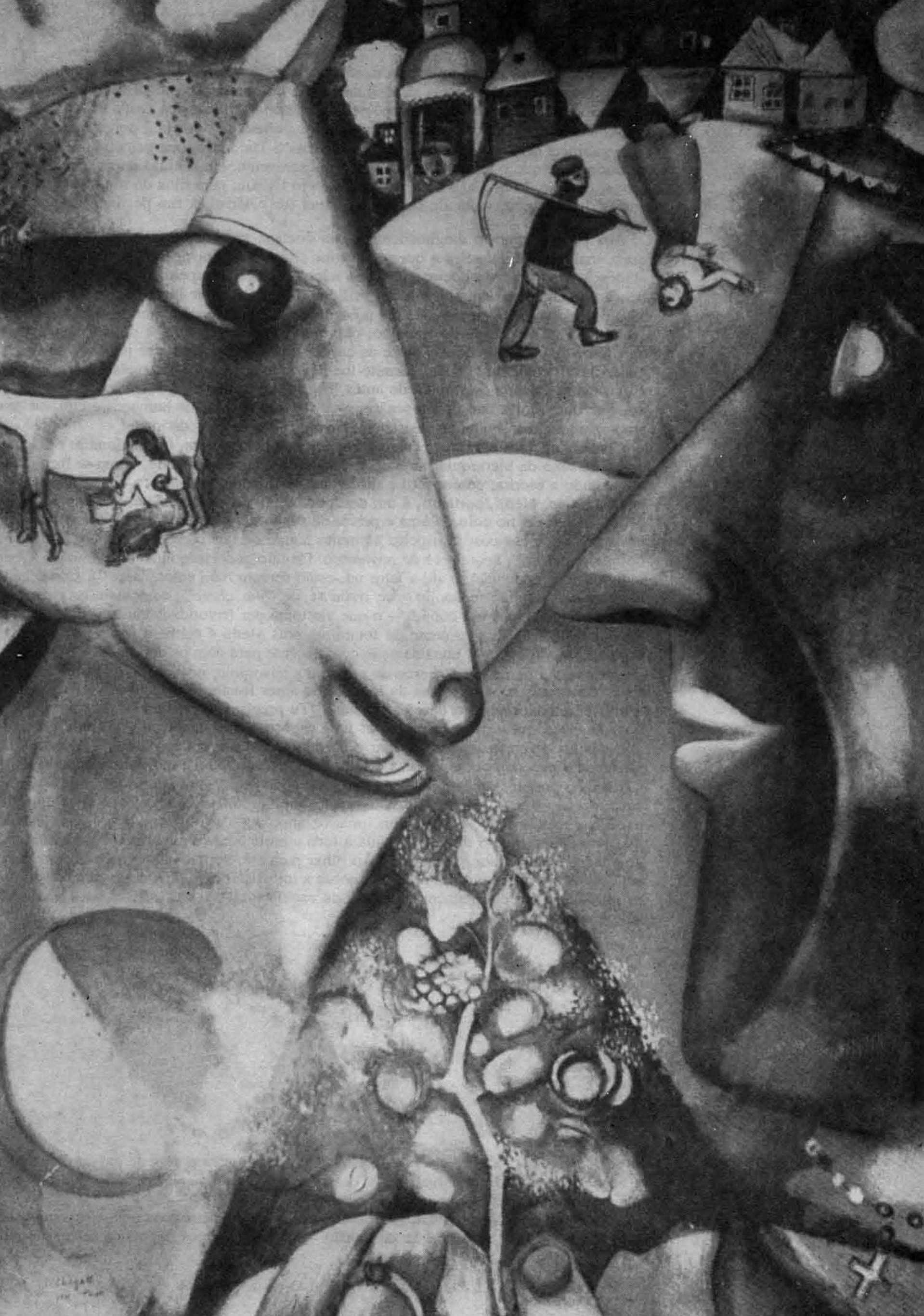


de personalidade, o desconforto com sua posição subalterna, a ambição que o perderá para o mundo dos burocratas sãos, uma pitada de confuso nacionalismo, querelante e pretensioso ("Que tolos esses franceses!... gostaria de pegá-los todos e dar-lhes uma boa chicotada"), por fim o chefete perseguidor e cheio de "inveja... porque o meu lugar é no gabinete do diretor, onde aparo suas penas". Tudo isso, mas principalmente a desconformidade que o leva a sair do papel de escrevente, em sentido duplo, para interessar-se, curioso do que não é de sua conta, pelo Estado, pela filha do diretor, pelas conversas de cachorro, voltando depois ao papel (do Diário), a fim de fixar suas impressões.

Áos poucos também diagnosticamos sua doença: trata-se de humilhação perscrutadora, mal terrível daqueles a quem o destino situou numa posição mesquinha e estática, atados à superfície de documentos que não lhes dizem respeito, sem lhes conceder a bênção da completa estupidez, antes infligindo-lhes laivos de imaginação. Este mal vaise agravando ao longo do mês de novembro, juntamente com sua desilusão. Aksenti Ivanovitch já não cuida do trabalho, deixa que o chefe desconfie de seu louco amor, apossa-se da correspondência entre as cadelas, de cuja existência se inteirara ao surpreender-lhes a conversa. O ócio permite-lhe pensar e ver. Logo, não mais consegue voltar à existência humana e estúpida de antes. Ele se vai tornando igual aos mascotes de luxo, que outra coisa não fazem senão espiar de fora os hábitos humanos e cultivar seus amorezinhos inconseqüentes. $\mathrm{E}$ isso aos quarenta e dois anos de idade!

Compreendemos agora o recurso à correspondência canina. $\mathrm{O}$ funcionário é um cãozinho de luxo da hierarquia burocrática, mais ou menos aprumado, como se fora gente, dominando a escrita, porém fútil e supérfluo, destinado a parasitar, a comer as sobras, a conformar-se. Medji, portanto, é um desdobramento do protagonista, que bem desejaria ocupar seu lugar no colo da ama e privar de sua mesa. Mas esses pequenos animais são observadores e críticos: "Suspeito há muito tempo de que o cachorro é mais inteligente do que o homem", anota a 11 de novembro. De fato, a correspondência canina está bem redigida ("a pontuação, e até a letra iat, estão sempre bem empregadas"). Como gente fina, as cadelas dão-se ao luxo de tratar-se de "ma chère", comentam as paixonites primaveris dos amos e a comida - o que ele toma por frivolidade canina, mas que seria melhor qualificar simplesmente de feminina, pois Medji é também Sophie -, lamentam ter de comer sobras, por consideração complacente para com os donos. Não é difícil observar como a humilhação cresce de par com a misoginia, no espírito do pobre Aksenti. Estes dos temas convencionais da loucura do amor frustrado tornam-no risível. Atribui a uma criadinha que cora desejos sexuais ("Tu precisas, pombinha, é de um marido"), quando ele é que está a suspirar por uma esposa; arrota ambição ("Grande coisa um conselheiro de corte... posso chegar a coronel e... a um pouco mais...”), quanto mais claramente padece com a pobreza e falta de horizonte. Nesse momento delicado de interrogação projetiva acerca de si mesmo, é quando, fatalmente, caem-lhe sob os olhos a comunicação que Medji faz do namoro de Sophie com o Sr. Teplof, "um fidalgo de corte", e a descrição de certo funcionariozinho, de "cara horrorosa", cujos "cabelos parecem palha" que o diretor "manda a toda a parte como a um criado", acrescentando ao quadro irônico esta ignomínia: "Ao olhar para ele, Sophie não consegue conter o riso". Após breves e sentidas reflexões sobre a injustiça dos títulos desse mundo, o mísero retratado faz "em pedaços as cartas da cadela tola", e por três semanas não temos dele qualquer notícia.

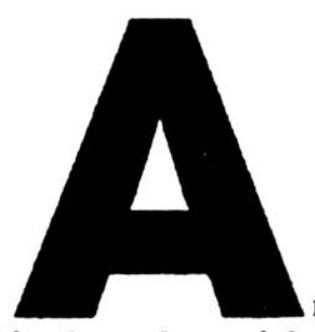

e ao desenlace, tão previsível, aliás, desse dramazinho ridículo, convém que nos detenhamos naquilo mesmo que o torna caricato.

A loucura de Aksenti Ivanovitch é-nos mostrada em seus produtos. Estivemos sempre, durante a fase de formação do delírio - e continuaremos depois da revelação deli- 
rante -, na superfície aparencial dos graves acontecimentos que lhe remoem a alma. A intenção de Gógol é satírica, já se vê; caso ele nos apresentasse a lógica interna das lucubrações de sua personagem, aquilo que é só extravagante tornar-se-ia decerto perturbador e conseqüente. Ficaríamos intrigados no mínimo, quem sabe repugnados por uma articulação do mundo estranha, mas reveladora do absurdo da vida burocrática e da aparência enganosa do pensar quotidiano. Assim não; as imagens é que se tornam absurdas, porque encadeadas num processo de pensar que não é o delirante; ou melhor, que corresponde ao segundo momento do delírio, à superfície que este exibe a título de relato; donde valer-se, com justeza, o conto, de um Diário. O relato supõe uma domesticação prévia do pensamento louco, normalizada a cadeia do raciocínio, ao preço de tornar completamente descabidas suas premissas. A conversa dos cães, mais que uma alucinação, testemunha a premissa louca da lógica do delírio que se transveste em razão normal, e assim o são também a ć́nica correspondência, a estatura descomunal do diretor, a inveja suposta do chefe, as "atenções especiais" de Sophie para com Aksenti, etc., etc.

De hábito, consideramos a vida quotidiana una e coerente, todo o discrepante supõese ser exceções devidas a uma percepção errônea, à ilusão ou a alucinações. Mas o real, produtor do mundo humano, comporta diferentes "campos" de eficácia, domínios distintos, gerados e ordenados por regras incomensuráveis entre si. Cada campo possui sua lógica e contém premissas adequadas, cada campo parece natural e único, quando nele estamos; contudo, ao passar de um campo do real a outro, mudam as premissas e alterase a lógica de produção, de forma que, vistos de um campo, os demais pareceriam francamente estranhos. Como a psique tamberm. opera por campos equivalentes e cada campo do real também o e da psique, consolida-se o perfeito casamento entre sujeito e mundo, até que algo produza um descompasso. Nisso consiste, antes de tudo, a loucura: a psique desencontra-se dos campos do real, deparando-se, sem preparo algum, com a lógica de concepção de relações humanas que, flagradas fora de seu campo próprio, se mostram absurdas e artificiais. A distância entre dois campos do real quotidiano é idêntica à que medeia entre sanidade e desvario.

Construir um delírio é, pois, obra dif́́cil e árdua, decididamente não é para quem quer. A partir de um estado prévio ou "limiar", conceito ao qual ainda voltaremos, o homem em vias de tornar-se delirante sofre um desmoronamento de seu sistema de representações de identidade e realidade. Perde a adequada articulação entre ambas que, em condições normais, garante, ponto por ponto, a correspondência entre representação do real e representação de si mesmo; pois nossa identidade não é um fato interno, mas certa adequação e constância da apreensão do mundo. $O$ efeito inicial de semelhante catástrofe é un mergulho no real; ou seja, a consciência impregna-se da mesma estrutura de produção que cria, num só movimento contínuo, horem e mundo humano. Na vida quotidiana, o real está opacificado por uma função benévola e caridosa, a "rotina", que separa e harmoniza seus campos, elidindo, no processo, a presença de sua ação produtora; vivemos vidas comuns, precisamente por nos estar tolhida a visão da forma pela qual se produzem nossas relações: a consciência enraíza-se no real, mas só o visa sob a forma da representação domesticada que é a realidade. Quando a organização rotineira se desagrega, é como se, trepando a árvore do convívio habitual, fôssemos dar nas rázes: o mundo mostra-se fabricado e estranho, enquanto a lógica racional, que organiza os produtos acabados da consciência, mescla-se com a lógica de sua concepção, antípoda absurda. É tão-somente um equívoco vulgar o que nos leva a projetar teoricamente a lógica do já concebido sobre a profundidade da concepção, imaginando ser o inconsciente uma segunda consciência e o real, uma realidade oculta. Real e inconsciente - ou, com mais rigor, desejo - formam um continuum produtor, que obedece a uma lógica própria, inumana, precisamente por ser constituinte e fundadora do pensar. Mirados de um ângulo inadequado - ou deveríamos dizer adequado? -, os campos do real desnudam-se implacavelmente: no conto, o mundo da burocracia estatal deixa ver seu esqueleto vazio, quando a desconformidade de Ivanovitch desloca seu ponto de fuga e registra o resultado no Diário.

Tal mergulho dura pouco, para o observador; para o sujeito da experiência psicótica, dura o mesmo tempo da eternidade, nem pouco nem muito, o tempo todo, simplesmente. Depois, há que voltar a viver num meio compartilhado com os demais. É então que surge o que propriamente se chama delírio. Com os ingredientes imagéticos que o mergulho no real evidenciou, mas sobretudo com resquícios da lógica absurda de concepção, misturada à razão comum, ele busca organizar a experiência em forma comunicável para os outros e para si. O delírio é a história de um mundo sem história, contada por um estrangeiro que se quer fazer passar por conterrâneo. Ele explica o mundo quotidiano, 
pois é este que agora se lhe defronta como um problema a resolver. Esmera-se em dar razões, excele-se em tudo explicar, para voltar ao convívio comum - o que ainda mais o isola, pois o comum dos homens não necessita de explicação alguma para sua vida. Todavia, a lógica de concepção que o contaminou torna suas razões sempre deslocadas e um tanto nauseantes, porque expõem as entranhas do espírito, de todo espírito, como uma barriga aberta que passeasse despudoradamente em plena praia. As imagens que lhe ocorrem, por seu lado, soem ser cômicas, pois tendem aos grandes temas da vida e da morte, do poder e da paixão, embrulhados com as mesquinharias do dia-a-dia, bem como elementos híbridos e fantásticos, cuja natureza estudaremos adiante, e com os mais recônditos sentimentos de egớsmo, de cobiça e inveja, de ambição e luxúria, que as boas maneiras psíquicas mandam guardar para uso pessoal.

Essas imagens, que combinam conversinhas de cães com uma grande paixão, não teriam grande eficácia sobre o leitor, condizendo até com a distância que prescreve o espírito da burla, se Gógol não imprimisse ao relato um caráter de falsa interioridade, que nos reaproxima das figuras insólitas. É como se quisesse dizer: "vejam, ar está o que é ficar doido". Então o burlesco deixa a superfície do conto e penetra a personagem, desnudando o aspecto intrinsecamente ridículo de todo delírio, quando contemplado do alto e de fora. Este fora-dentro, que transporta para o interior do protagonista a visão de quem só poderia ser observador da loucura, transforma-o, por sua vez, num observador privilegiado tanto da loucura humana geral quanto da própria. Ri das pretensões dos colegas e dos superiores, porém alimentando as suas, ironiza o sexo que o abrasa, cospe na burocracia, reduz os homens a cães, mas se identifica com eles. Eis aqui parte do mistério do redator do Diário; ele tenta superar-se: "Saber tudo; todos os pensamentos". Trata-se, porém, de uma volta por baixo da sombra, movimento impossível e contraditório que arrasta em seu cerne o objeto que quer desvendar, o próprio absurdo humano. Se Ivanovitch fosse uma figura inteiramente séria, o sarcasmo seria insuportável, pois seu interior revelado mostraria a fonte de toda a irrisão concebível: pensar-se pensando, sentir-se sentindo, enxergar o próprio olho. Quem pode dizer, contudo, que Gógol não pretendesse tal superação pelo avesso, ao satirizar, em Aksenti, o burocrata que brevemente fora e o louco que haveria de ser?

Todavia, como a torção interna do pensamento rumo à lógica de concepção não afeta o Diário - não há condensação, paralogismos, reversão de implicações, etc. -, a presença do absurdo somente se manifesta nas imagens que o figuram, e estas últimas suportam o peso todo da caricatura. O grande diretor, de pensamentos profundos, mas que não profere duas palavras concatenadas, adquire, em nossas mentes, a estatura do medalhão machadiano. O chefete é o que é, e não é grande coisa, a julgar pela banalidade dos conselhos que prodigaliza ao herói: "reflete bem", "cria juízo". Sophie não é muito mais do que Medji, amante de belas roupas, de bailes, de umas suíças negras. $\mathrm{O}$ mundinho da repartição tampouco esconde sua nulidade. Aksenti, por fim, quase se alça ao patético: um aparador de penas enamorado. Numa palavra, o ridículo é inerente ao universo retratado; sobreleva-se, contudo, ante a meticulosa perscrutação do doido, que já começa a enxergar demais o estofo proibido da realidade. Um louco em seu louco mundo, exatamente paralelo ao homem normal em seu mundo normal: este, adaptado; aquele, crítico.

Aksenti identifica-se com todos: com o diretor e com a filha, com os grandes e com os mimados, com os humilhados ("Falta-me dinheiro, eis a minha infelicidade") e com os titulados. A ambição do diretor restringe-se a uma condecoração, Aksenti observa-a criticamente, porém segue-lhe os passos e pretende ser nobre. Nem a burocracia escapalhe à identificação e à crítica: goza o prazer da proximidade com os maiores, é serviçal ("aparei para ele vinte e três penas"), frustrado ("e para ela... ai de mim!... para S. Ex"a , quatro"), diligente e depois relapso; entretanto, viola a regra de ouro do bom funcionário, almeja alturas e quer conhecer as profundezas.

O esparramar-se identificatório é outro motivo de ridículo no delírio. $\mathrm{O}$ delirante é tudo, se o humanista pode afirmar que nada lhe é alheio do que seja humano, Ivanovitch acrescentaria que nem sequer é alheio ao canino. Durante a fase preparatória do delírio, há uma adsorção paulatina de todos os fatos e de todos os sinais, que vão aderindo à pele da sua alma. $O$ mergulho ainda não se deu, mas a incredibilidade da representação identitária já é patente na personagem, ele oscila entre admitir sua condição e sonhar hipóteses grandiosas. Entrementes, quase qualquer figura do mundo contém sinais premonitórios e serve de inspiração a um pequeno enredo fantástico, como peça solta do quebra-cabeças que, de súbito, há de se compor inteiramente. Não há praticamente nenhum elemento neutro na realidade, todos dizem respeito ao aprendiz de delirante; ou seja, a dimensão identitária, que existe em cada ponto da realidade vivida pelo 
sujeito normal, é posta em evidência e centuplicada no limiar do delírio. Este caráter microcósmico contribui sobremaneira para o efeito de irrisão. Como tão grandes questões - nobiliárquicas, nacionais, universais - concentram-se em figura tão miúda? Como se misturam na mesma sopa os destinos do homem, os rumos das nações, o conhecimento das essências, com penas aparadas, bilhetinhos de cadelas, rubores de domésticas? No entanto, nosso pequeno funcionário reivindica a elevação da origem ("Serei eu, porventura, da arraia miúda?"), ele não é "um mujique" nem é "filho de alfaiate". A própria estrutura hierarquizada do funcionalismo tzarista encarrega-se também de mimetizar o delírio, em sua força de atração centrípeta, dando emprego, título e algum tipo de uniforme a qualquer terceiro filho de proprietário meio arruinado que falhou em ser soldado. A aspiração incessante da periferia para o interior do sistema delirante, que dele faz uma miscelânea de temas contrastantes, preside de forma idêntica a formação da hierarquia funcionária; paradigma da loucura de Ivanovitch e tão cômica quanto esta. Em suma, não só nosso pequeno herói é louco desde o início: seu mundo também o é e era antes dele. Quando atribui a causa de sua desventura a tramas do chefe de seção, que lhe teria votado "um ódio de morte", decerto dá mostras de paranóia, mas não deixa de provar certa lucidez genérica - se não o chefe, o sistema é mortal.

Como que aludindo ao nó do delírio, à impraticabilidade de enxergar os próprios olhos que vêem o absurdo ou de conhecer o ato de concepção que cria realidade e identidade subjetivas em discordância, Gógol começa a insinuar esta quintessência do ridículo que é o tema do nariz. Pois o nariz é aquilo que não vemos, mas exibimos empertigado, significa nossa cegueira ao mais proeminente de nós mesmos, à exterioridade de nosso corpo e de nosso espírito. Este nariz que se veste de homem e sai a viajar, noutro conto célebre do mesmo autor, metonímia transeunte, já aqui parece representar o homem inteiro, louco, exibicionista, falto de crítica. Ao contrário das sombras de Andersen e de Oscar Wilde, que transportam consigo a alma alienada do homem, o nariz transporta-lhe as pretensões mais risíveis - o orgulho de Cyrano de Bergerac, os puxões de nariz que simbolizam a suprema humilhação em tantas histórias russas. Em consideração a isso, talvez, e porque o ridículo aqui faz o delírio, na mesma medida em que por ele é criado, o mês de dezembro, e com ele o desenlace, principia aludindo a um nariz, figura que depois irá proliferando no conto.

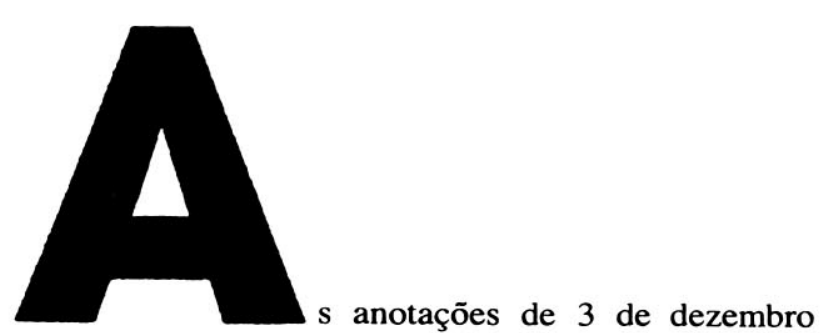

chegamos enfim e, com elas, ao limiar da insofreável decolagem rumo ao delírio consumado. "Não pode ser! É mentira! Esse casamento não se deve realizar", exclama desesperado Aksenti Ivanovitch. Por que razão é ele preterido em favor de um fidalgo da corte, se ser fidalgo não acrescenta "um olho à fronte" nem seu "nariz é de ouro"? Pese a sensatez aparente de tais questões, o malogrado amante está a mexer num assunto perigosíssimo. De fato, tanto quanto dele sabemos até aqui é que tem um cargo e um título, apesar de ínfimo, na hierarquia funcional. Não obstante, por coerência teórica, é necessário inferir certa dose de pusilanimidade, um excesso de apego às condições estáveis e de aversão à mudança. Ivanovitch não deve ter nunca lutado com a vida, terá sempre temido despojar-se de um estado ou de uma auto-representação, para abalar-se ao arriscado e desconhecido. Esta estrutura patológica, a que chamo "falta de sentido de imanência"'(2) - isto é, uma certa incapacidade em apreender-se como sujeito estável, quando as representações concretas da pessoa se alterám sensivelmente -, costuma levar ao exagerado apego a qualquer forma de auto-imagem, mesmo que insatisfatória, a fim de preservar a identidade. Nossa identidade é assegurada de duas formas distintas: pela constância de certas representaçōes axiais e por um sentido (pré-representacional) de sermos o autor de nossos pensamentos e o sujeito de nossas percepções e memórias. $O$ turista que percorre apressadamente terras exóticas, fotografando sem cessar, pode depois localizar-se nas imagens registradas, mas ainda se as não reconhecer, possui
2 "Falta de sentido de imanencia". "patologia dos possíveis", "crença", representacional" e tantos outros conceitos aqui sucintamente expostos são discutidos em pormenor em meu livro Andaimes do Real, 3 vols., cujo primeiro tomo será reeditado pela Editora Brasiliense, São Paulo, em outubro de 1991. Ou, para retor imediata e menos detara reler éncia imediata e menos detalhada: Clínica sicanalftica: A Arte da Interpretaçăo. São Paulo, Editora Brasiliense,
1991. 
sempre a garantia de que é sua a câmera que as captou; ele está na câmera, talvez mais ainda que nos lugares visitados, nela se deposita seu sentido de imanência. Se tal sentido é fraco, entretanto, é melhor nem sair de casa, pois só os fatos mais vulgares se poderão registrar, por medo de perder a identidade junto com o mundo conhecido; e é assim que certo tipo de turista vai procurar, e encontra, hot-dogs pra lá da praça Jemaa el Fna, em Marrakesh, em Chittor ou Hangaroa, ou ainda no hotel Pribaltiskaya, em São Petersburgo. Também na vida quotidiana, o espaço que medeia entre auto-representações muito discrepantes é uma zona de perigo, onde aquele que carece de razoável sentido de ser-se, pode se ver precipitado num vazio identitário. A defesa mais comum consiste em manter estrito controle sobre o meio circundante, buscando torná-lo constante, tanto quanto possível, ou tão-somente discriminando os estímulos mais comuns.

No caso presente, faltam indicações inequívocas dessa carência, mas podemos supô-la, não só da arquitetura da personagem, mas principalmente do meio hierarquizado onde vive. Pois a hierarquia é um vazio escalonado. Ali, o homem só vale pela posição relativa que ocupa e a ocupa unicamente por um título, por uma auto-representação sancionada e epidérmica. Por conseguinte, não creio estar violentando o espírito do conto, ao imaginar falta de sentido de imanência no conselheiro-titular: quando menos se trataria de uma genérica doença profissional.

Por causa disso, as perguntas que o desespero lhe inspira são, em si, sobejamente perigosas. Tem dois olhos e um nariz, cujas funções comparte com a nobreza e com os servos, e uma posição das mais comuns, cujas funções tampouco o identificam dentro do sistema burocrático de pura exterioridade. Mas se lhe falta também um asseguramento imanente, brincar no trapézio das imagens de suas possibilidades de ser pode resultar num tombo sem precedentes. No entanto, desavisado, ele pōe-se a conjecturar, na mesma anotação do dia 3, incitado pelo despeito: "Talvez eu seja algum general ou conde, parecendo apenas conselheiro-titular".

$\mathrm{O}$ segundo ingrediente que reputo fundamental para o limiar delirante aparece aqui; chamo-lhe "patologia dos possíveis". Trata-se de uma condição sui generis do sistema representacional, em que a própria hierarquia das possibilidades de ser apagou-se e, portanto, os estados possíveis afetam o sujeito como se fossem reais. Tem esta condição algum parentesco com a má-fé sartreana, a doença do ser-para-si, todavia seu sentido está invertido. A pessoa não afirma uma de suas possibilidades de ser, fundada na liberdade do vir-a-ser, como o covarde fuzilado do Huis Clos. Pelo contrário, a liberdade dos possíveis faz com que ela se transforme numa coisa atrás de outra, ao ser tomada, fugaz mas violentamente, por impressões passageiras ou por alguma palavra de sentido ambíguo, mercê da deterioração de seu estatuto de realidade. Pensemos em como isso pode suceder. Como tudo aquilo que é-o somente por ser possível - o impossível não ocorre -, e o possível não se distingue intrinsecamente do real, segue-se que ser real e ser possível são uma e a mesma coisa, cabendo ao real a condição de apenas possível e, a este último, a de quase-real. Com efeito, mesmo na vida comum, nunca vivemos amarrados à realidade material. $\mathrm{O}$ quadro que planejo comprar já se mostra levemente delineado na parede fronteira, forçando os outros a se rearranjarem. Posso descobrir que sou um rico herdeiro amanhã cedo, assim como posso amanhecer o psicanalista que julgo ser; são duas possibilidades, iguais em gênero, mas desigualíssimas em probabilidade; meu sentido dos possíveis discrimina-as e, como não me fio na primeira, preparo-me para trabalhar amanhã. Na patologia dos possíveis, a confusão dos graus de probabilidade equaliza todo o horizonte de meu ser possível, tornando-me presa fácil para qualquer tipo de identificação. Ainda assim não me poria a delirar, se dispusesse de forte confiança intuitiva em ser eu mesmo o autor de minhas idéias: haveria de ser imensamente sugestionável e desconfiado, temeria a conversa fiada e os devaneios, duas ocasiões onde os possíveis pululam; talvez me convertesse num obsessivo, mas ainda saberia quem sou. Essa condição pantanosa do ser psíquico submete o sujeito à perpétua desconfiança e a súbitas iluminações, demandando excessivamente seu sentido de imanência. Ora, como vimos, o sentido de imanência não parece ser o forte de Aksenti Ivanovitch...

Ele se indaga: "Que quer dizer ser eu conselheiro-titular? Talvez eu mesmo ignore quem sou. Veja-se quantos exemplos disso temos em toda a história...”. E segue enumerando as possibilidades ocultas de camponeses e burgueses que se descobrem subitamente barỗes ou magnatas. O hábito faz o monge e o general: "apareço em uniforme de general, com dragonas... Em que tom me falará a minha bela senhorinha... e nosso diretor, ambiciosíssimo". É possível sim, mas se o possível avizinha-se do real ("Será que eu não posso neste mesmo instante ser nomeado general governador...?"), o real entra em crise, desfigura-se em mera eventualidade discutível ("Gostaria de saber por que sou conselheiro-titular? Por que justamente conselheiro-titular?’). 
Ei-lo, pois, no limiar delirante, conjunção de falta de sentido de imanência e de patologia dos possíveis. Como está o homem que habita esse perigoso umbral? Pode ser capturado pela atração gravitacional de quase qualquer representação possível e sentirse-á outro, posto que brevemente. Para resguardar-se desses trânsitos abruptos, procura recolher-se ao mais familiar, furta-se ao contato interpessoal, tão fértil em sugestōes e tão atraente, e monta um sistema de julgamento fechado que não dê margem a dúvidas; tal e qual nosso herói, encerrado em seu quartinho a sonhar ou ensimesmado na repartição. Em tudo e por tudo é o limiar delirante aparentado ao preconceito. Como o preconceituoso, o sujeito, nesse limiar, restringe-se cada vez mais a crer numa só forma de verdade e a representar-se reduzidamente, por meio de um núcleo concentradíssimo de opiniões inamovíveis e de umas tantas idiossincrasias. Deve saber de tudo, porque cada zona ensombrada do mundo esconde uma atração fatal que o pode arrastar ao desconhecido e à perda da identidade enfraquecida: "todas as molas, tudo hei de descobrir", escreve Aksenti Ivanovitch.

Fora do núcleo escolhido da identidade defensiva, as representações não oferecem a menor garantia. Não é dif́́cil o entender, se lançarmos mão de um modelo simples e esquemático. A superfície identitária, no indivíduo normal, contém uma área central definitória, fortemente assegurada pela crença - essa função psíquica que garante a permanência de nossas representações de realidade e identidade; depois, outra região, menos central e menos assegurada, que reúne as idéias e imagens em que confiamos, sem que nos sejam vitais; por último, na periferia do sistema, uma zona desacreditada de exceções à identidade, onde têm guarida as representações híbridas, as quimeras e fantasmas que combinam elementos de nossa subjetividade com figuras da realidade, emprestando intenções projetadas até aos objetos inanimados, tudo aquilo enfim que juramos não haver ou não ser nosso, pelo menos de dia, pois que à noite nos assombra. Se as regiōes centrais se encolhem e minguam até serem pouco mais que um ponto - onde ainda está o nome próprio, a posição que se ocupa, casa e um velho casaco, como o do conselheiro-titular -, a periferia cresce proporcionalmente, erigindo uma montanha de exceções aparentes à regra do quotidiano, que são atribuídas à malévola intenção alheia (no caso presente: à inveja do chefe de seção, que lhe cobiçaria o lugar na sala do diretor e as atenções da filha: "inveja-me, decerto, por haver percebido algum sinal de simpatia dirigido a mim e não a ele"). Dessa zona de exceções, repleta de figuras fantásticas, algumas se deslocam, de quando em vez: cãezinhos falantes ou intuições sublimes, neste triste caso.

Não há como resistir à sua atração; a combinação de falta de sentido de imanência e patologia dos possíveis produz um ser camaleônico, um esparramar-se identificatório, já o vimos.

Por fim, as exceções desmoronam sobre o núcleo identitário, povoando-o de representações incríveis e mutáveis, que não suscitam qualquer confiança da identidade. Do outro lado está o real que, deixando de ser realidade consensual e rotineira, exibe descaradamente sua função produtora das relações humanas; estas se mostram fabricadas e artificiais, cada qual em seu campo gerador, que também se mostra; nelas não há que pôr confiança tampouco. E como não é possível viver em permanente dúvida e mutação, assim que uma representação suficiente o mundo oferece, a identidade é, por assim dizer, expelida para a realidade, lugar onde se concretiza, adotando a forma estávei e substancial de uma coisa entre outras coisas, reifica-se num sentido final, sustentado à outrance pelo sujeito: Cristo, Napoleão, Fernando VIII. Sobra, como já se mencionou, o problema de o que fazer com o resto da realidade comum e com o resto da subjetividade. Esses restos ameaçam a nova identidade reificada, o sujeito deve defendê-la, prová-la incessantemente contra a suspeita que o domina, mas que atribui aos demais. É a hora da narrativa e das explicaçōes. O último ato de nosso drama revelará exatamente issu. O delirante - pois agora já o é completamente -, ao ser tocado por uma representaçâo suficiente de si mesmo, imerge nela inteiro e lá se congela, tentando justificar agora a estranheza do quotidiano que antes habitava.

Espicaçado por um desengano amoroso, desgostoso de sua condição: que mais se requer para que Aksenti Ivanovitch avance um passo, cruzando o limiar? Lê-se em 5 de dezembro: "Toda a manhã de hoje li os jornais". Ócio e meditação, condições para buscar uma representação suficiente; falta uma fonte de inspiração. Mas esta, o jornal lhe proporciona, ao tratar da disputa em torno da sucessão de Fernando VII. "Na Espanha estão acontecendo coisas estranhas. Escreve-se que o trono está vago. Diz-se que ele deverá ser ocupado por certa doña. Mas uma dona não pode ocupar um trono... deve ser ocupado por um rei", e mais à frente: "Há um rei; apenas, ele se encontra em lugar desconhecido". Já agora, nada falta. 
Se a lógica delirante está oculta na personagem desta história, e devemos recolhê-la aos bocados, por leves sinais, a imaginária do delírio continua a florescer, ridícula e viçosa. Uma dama no trono?! A misoginia do desengano nunca o permitirá. É bem verdade que esta é creditada à conta das grandes potências, à Inglaterra, à Áustria, ao tzar russo. "Quem pensa que $\hat{\varepsilon}$, a bela senhorinha que ocupa o trono de meu coração?" talvez estivesse dizendo de si para consigo. "As mulheres crêem-se muito - cãezinhos mimados, gatinhas assanhadas; eu, nós, os homens, os reis da criação, poremos ordem nesse desleixo, imporemos nosso cetro altivo." Ah, pobre funcionário de quarenta e dois anos, "sem meio copeque de seu", os cabelos como feno - é você o rei e o real? Por que não? O que é possível é real de alguma maneira, e se não sou eu mais do que aquilo que me representa... - responderão em dueto a patologia dos possíveis e o prejuízo do sentido de imanência.

Em 8 de dezembro, já não vai à repartição, medita, o negócio da Espanha não lhe sai da cabeça. "Há um rei, em lugar desconhecido..."

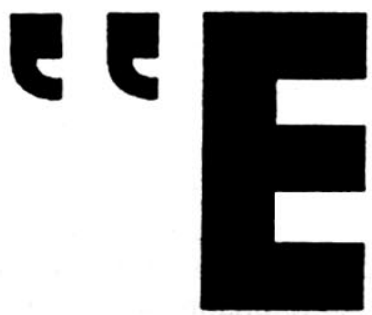

ste rei sou eu." Dadas as premissas, eis a conclusão. A revelação delirante cai-lhe em cima de repente, "como um relâmpago". "Só hoje é que o soube." E que dia é hoje? 43 de abril.

A partir desse ponto, Aksenti Ivanovitch, que se pusera até agora algo metafísico, readquire plena certeza de si. As imagens delirantes atropelam-se, crescem em riqueza fantástica, tornam-se surpreendentes mesmo para a cabeça de um louco. É que daqui para a frente o ator parece ter superado a sua personagem, ou, ainda melhor, o delírio suplantou-os a ambos. Como entender que um doido, tão cabalmente doido, desde o início do relato, a ponto de meter o nariz nos negócios caninos, viesse a sofrer de súbito tamanha transformação, verdadeiro delírio dentro da atmosfera delirante anterior? Psiquiatricamente, isso talvez não seja inteiramente ortodoxo, mas tem sua lógica. Digamos que a representação suficiente se revelou no espaço vicário de sua já trôpega e desgostosa identidade, tal como vago estava o trono da Espanha, fulminando instantaneamente o burocrata. Se não um delírio real, pelo menos a teoria do delírio encontra-se no conto excelentemente representada, porque estamos aqui às voltas com um delírio-tipo, com a convenção de um delírio, tal como o representa a imaginação comum, porém elevado a alturas incomuns. $\mathrm{O}$ delírio convencional nada mais é senão a distância entre o real humano e sua representação rotineira, revertida em conhecimento torto. Vem daí que, convencionalmente ainda, sua expressão seja a fantasia irrestrita; isso tematiza o conto, não o monótono delírio psiquiátrico, mas uma espécie de teatro vaudeville a representar a teoria do delírio, se se encarnasse puramente em gente e saísse pelo mundo. Custa-nos um pouco sair da contemplação maravilhada dessa imaginária surrealista avant la lettre que Gógol armou para Aksenti Ivanovitch, e ensaiar mais algumas pequenas observações. Porém, coragem.

Atingido pelo relâmpago da revelação, o novo rei dá-se conta de como sua vida e seu entendimento eram opacos até então. Como se pudera crer um reles conselheiro-titular? Sorte que não tivesse "ocorrido a ninguém trancafiá-lo" por isso "numa casa de loucos". O delírio joga, a essa altura, com a própria questão do absurdo e da loucura. Tocado por uma representação suficiente, Aksenti resolve de supetão os problemas do possível e da imanência. Adere à representação por inteiro, sabe-se alguém, enfim, o mundo adquire outra forma, bem arranjada. Comparada com a nova situação, mente e mundo anteriores têm o sabor vago e duvidoso que só cabe qualificar de desvairado. É que, no interior do delírio, a questão mesma do regime de verdade conserva toda sua vigência. $O$ delírio é um campo diferente, e a presença, lado a lado, de dois campos, o "normal" e o "delirante", põe em tela de juízo o problema do conhecimento; ninguém se ocupa tanto da loucura como o psicótico, malgrado a opinião leiga sustentar o contrário. Este assentamento diverso das propriedades veritativas surge, para nosso herói, 
como uma autêntica dispersão na inteligibilidade do mundo. Ele sabe agora, por ter penetrado o real, que o mundo quotidiano se rege por critérios falsamente absolutos, ventos de opinião que dirigem as pessoas a crenças determinadas, fabricadas e mutáveis. "E tudo isto, penso eu, vem do fato de a gente imaginar que o cérebro humano se encontra na cabeça. Não, decisivamente não: ele é trazido pelo vento do lado do mar Cáspio." Vem daí que o quotidiano anterior pareça-lhe agora uma brincadeira. Ele trata a todos com a bondade dos iluminados, vai à repartição, de pura troça, mas quando lhe dão um documento a assinar, apõe sıu nome verdadeiro: Fernando VIII.

O campo do delírio ocupar-se-á doravante com o duro problema de traduzir as ocorrências pertencentes ao campo da realidade comum. Construído um novo real, há que nele fazer entrar os dados da realidade comum. Isso se consegue pelo concurso de dois critérios: revelação crítica e hipóteses ardilosas. Ivanovitch recupera-se dos males do amor, ao descobrir que as mulheres, por natureza, só amam o diabo, revelação que culmina sua misoginia despeitada - ao passo que efetivainente repete um universal popular: "que todas elas procuram o diabo que as carregue...". Os "pais de alta categoria", de seu lado, querem dinheiro, honras, são uns ambiciosos que se fazem passar por patriotas, "uns vendilhōes de Cristo!'”. Seu poder de observação está intacto, mas livrouse das peias das convenções e pode denunciar desabusadamente a falsidade que o rodeia. Já as hipóteses explicativas têm o caráter mais ou menos costumeiro, nas psicoses, de órgãos ou agentes desconhecidos, de costumes exóticos ("cada louco com a sua mania", ele poderia dizer), de fatos insuspeitados. Mas com que gênio criativo! A ambição deve-se a um "vermezinho do tamanho de um alfinete", que habita certa "vesícula", situada "debaixo da úvula".

Levado ao manicômio, sua imaginação excede-se em vôos a serviço da retradução do universo circundante. "Eis-me, afinal, na Espanha", ele conclui. Se antes não se podia revelar na qualidade de rei, pela ausência de um traje digno - fantasia que tenta cumprir, reformando, por conta própria, seu uniforme de gala -, aqui já está livre para armar a alegoria completa. O carro que o leva ao hospício em meia hora alcança a "fronteira espanhola", mercê da revolução industrial, que dotou a Europa de meios de locomoção tão eficazes. São estranhos os vezos espanhóis: rapam-lhe a cabeça real; dão-lhe bordoadas, que ele traduz por cerimônia de investidura - tradicionais esses castelhanos!; jogam-lhe água gelada no crânio para esfriar as idéias, isolam-no, vigiam-no. Tudo isso ele vai procurando entender dentro do campo do delírio, que nos dá a impressão, diga-se de passagem, de ser o único adequado à compreensão de tais maus-tratos. Querem tirar-lhe da cabeça as idéias à força, ele se aferra a elas com mais força e denodo. Um enfermeiro é inicialmente chanceler, mas tantas pancadas lhe dá, que se metamorfoseia no Grande Inquisidor.

E assim vai o pobre Aksenti aprendendo a dura lição de que, se os campos do real são alternativos, alguns deles estão mais bem armados, de porretes, do que os outros. Com isso, um pouco de juízo penetra em seu crânio, ajudado, naturalmente, por aspersões profusas de água fria, até o ponto em que suspira pela mãe, declarando-se doente. Vitória da saúde nosocomial? Não estejamos tão certos. Depois de suspirar, "Mamãe, tem piedade do teu filhinho doente!", quando pareceria que se curvava aos ditames da realidade, Aksenti Ivanovitch segreda vitoriosamente a frase final do conto: "Vocês já sabem que o rei de Argel tem um tumor exatamente debaixo do nariz?".

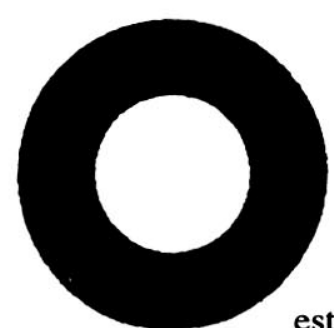

estudo psicanalítico do texto literário é tarefa ingrata. Dele, no mais das vezes, não resulta grande coisa, e isso por duas simples razões: a doutrina psicanalítica não se presta especialmente à interpretação e os analistas não estão acostumados a interpretar. Para bem interpretar, há que se deixar penetrar ate a medula pelo objeto, sem lhe atribuir sentido prematuramente. Ora, nosso forte é ter preparadas as interpretaçōes e dispará-las assim que o alvo se mostre a 
meia distância. Há um nariz nesta história; com efeito, há vários narizes empertigados. Mas um nariz, inequivocamente, é símbolo fálico. Logo, já temos por onde começar. Se os narizes não se vêem, trata-se de castração, vejam como o protagonista censura com "psius" seu impulso amoroso, como se pretende potente e onipotente. Nem é preciso continuar, todos já conhecem esta interpretação nalguma de suas versões mais populares. Virá Édipo, virão ciúme e inveja; a projeção não haverá de faltar à convenção psicanalítica, com boa razão até; regressão, ataques ao pai-diretor, temores de retaliação, depressão e mania, acompanhando os inevitáveis sentimentos persecutórios, completarão a mesa de abertura. E o conto estará entendido, quase sem necessidade de o ler.

Mas fiquemos no nariz. Que vantagem há em traduzir nariz por pênis? Porventura é o pênis mais conhecido que o nariz? Traduzindo o incógnito pelo desconhecido ganhamos algum saber? Não me parece, nem creio que pênis seja um significante mais primordial do que nariz para a compreensão desta história. Aliás, o nariz possui até certa primazia histórica no âmbito da psicanálise; a dupla paixão de Freud, pela cocaína e por Fliess, otorrino e confidente, teórico do nariz, antecedeu a teoria do complexo de Édipo e da sexualidade infantil, dando ensejo a que se inverta, se for do nosso gosto, a ordem de precedência: primeiro o nariz e depois o pênis, antes os pontos de estimulação sexual do nariz, depois a teoria falocêntrica. Nada disso tem qualquer importância, porém. A questão é de tempo. Para interpretar é preciso dar tempo ao tempo; meter primeiro o nariz onde não se é chamado, sem ver um palmo à frente dele, até que o objeto de nossa perscrutação se entregue por si mesmo; é mister quedar-se diante do nariz do conto até saber de que se trata, pois, como todo mundo sabe, dois narizes nunca são iguais. Por isso, é de pouca valia a aplicação da doutrina psicanalítica à obra literária; ela abrevia o tempo de consideração e leva-nos a concluir obviedades.

Mas as interpretações da literatura feitas por Freud são preciosas, quase posso ouvir a contestação. De acordo, o Estranho, por exemplo, é brilhante e fundamental para a psicanálise e até para a literatura. Sabem por quê? Porque a psicanálise é eficientíssima na interpretação da literatura, bem como das outras criações culturais da psique. A psicanálise, não a doutrina psicanalítica; o que significa apenas que a psicanálise é essencialmente um método interpretativo, sendo a doutrina uma decorrência provisória de sua aplicação. Consiste nosso método em deixar que surja para tomar em consideração. Deixar que surja significa pôr-se diante do objeto - de um paciente, de um texto -, sem atentar à particularidade alguma em detrimento de outra, e por tempo bastante para que se mostre um princípio de sentido, um tema, a ausência de um elo de lógica, uma contradição. Depois, é tomar em consideração; isto é, não conceder descanso ao elemento que, por incauto, se mostrou, mas aplicá-lo a outros elementos e setores do objeto, como interpretante; ler um texto com o nariz, se for este o caso. Ao dobrar uns sobre os outros os próprios sentidos presentes, denunciam-se os campos em que se assentava sua naturalidade aparente, o obvio torna-se estranho, rompe-se o campo da rotina e brotam sentidos novos. Repete-se a operação diversas vezes e então se organiza o conjunto dos sentidos numa prototeoria, que poderá servir futuramente de interpretante também.

É só isso? Onde entra a teoria psicanalítica, com todas as suas intrigantes figuras? Não entra, aŕ que está. Ou melhor, em vez de entrar, ela sai da interpretação, que a cria e constitui; talvez entre depois, mas só depois e ao modo de comparação, para o enriquecimento dos resultados obtidos. Freud não interpretava com a doutrina psicanalítica; esta nem existia, ele a estava inventando à medida que interpretava. Quer dizer: usando sua teoria nascente para revelar o sentido de histórias, valia-se destas, ao mesmo tempo, para criar a psicanálise - um método interpretativo, em primeiro lugar; remotamente, uma doutrina. Seu interpretante era reversível, a incidência recíproca do sentido nascente de dois textos, da teoria ainda infirme e de alguns contos, redundou em descobrimentos, como o do significado antitético das palavras. Mas pergunto: qual texto era o intérprete e qual o interpretado? Hoje, no entanto, quando a psicanálise tem um corpo conceitual espesso e às vezes pesado, é preciso prevenir que esmague nossos sonhos; para tanto, aconselha-se a deixar que as histórias interpretem a psicanálise, não o inverso.

Isso estivemos fazendo. Não procuramos descobrir o sentido psicanalftico do "Diário de um Louco", porquanto este não existe. O conto tem o sentido que tem, e o diz muito bem, muito melhor do que qualquer interpretação o diria, pelo menos. Com toda segurança, não é uma parábola expressamente escrita para ilustrar a teoria psicanalítica. Seu sentido, todavia, incidindo sobre certa forma de ver a loucura, nossa teoria do limiar delirante, por exemplo, abre-se em novos sentidos, ilumina a teoria nascente, ensina como é delirar - arte intrincada e obscura teoria do mundo. A rigor, só se deveriam interpretar obras literárias a partir de teorias nascentes e ainda bambas: a certeza mata 
teoria e interpretação, e aleija a história interpretada. Se é este que descobrimos o sentido oculto na melancólica história de Gógol? Como saber? Não falo duas palavras de russo; como assegurar que certas conexōes intrigantes não resultam de simples trocadilhos intraduzíveis? Para o analista - mas não para o lingüista nem para o literato -, este conto $e$ apenas sua apresentação, está escrito em português. Alguma informação pode ser útil, quando menos para não multiplicar tolices; talvez tenha utilidade para nossa interpretação saber, por exemplo, que Hussein Pasha, dey de Argel, foi deposto pelos franceses, em 1830, sob o pretexto de ter golpeado o cônsul da França com um espantador de moscas, ao cabo de complicada discussão acerca do pagamento de uma partida de trigo; mesmo que a Enciclopédia Britânica não ofereça comprovação alguma da verruga que ostentaria debaixo do nariz, de cuja existência histórica tampouco há que descrer. Sem embargo, o essencial de nossa interpretação ế realmente deixar que surja e tomar em consideração.

Desta história em particular surgiu o campo do delírio; não o de um delírio real, carregado das perturbaçōes geradas pela infiltração da lógica de concepção na superfície racional, que desorientam e espantam o analista; mas o campo da convenção do delírio, este sim, límpido como uma teoria. Sobre a teoria de Gógol dobramos a nossa, tendo por efeito aprendermos algo sobre loucos, narizes, burocracia, representação suficiente, imanência e possíveis - e lá no fundo o real e o desejo, insondavelmente à espera de nossas melhores explicações, para de imediato suplantá-las. A esse estrato não soubemos descer, nem ali nos arriscarfamos. Gógol, parece, esteve por lá, acolhemos agradecidos seu testemunho. Se o "Diário de um Louco" concentra elementos autobiográficos - mas qual história que os não tem? -, se é um jogo levemente sádico com contemporâneos e leitores pósteros, se exorciza alguns de seus fantasmas, se é uma história contada pelo prazer de contar, não cabe à interpretação psicanalítica decidir: Gógol, para nós, é só este conto. Pesquisamos a raiz humaníssima do ridículo, a interioridade exposta do delírio, percorremos seu campo; há que cuidar para não cairmos no ridículo, nós mesmos, inquirindo o que não é de nossa conta, como o infeliz Aksenti, pois com campos não se brinca. Aos mestres do campo, a Gógol e ao Diário, deixemos as últimas palavras.

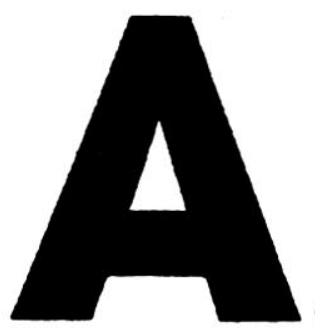

o cabo dessas considerações ligeiras e da triste história lida, encerremos nosso estudo do drama ridículo de Aksenti Ivanovitch com umas poucas reflexões sobıe a imaginária no campo do delírio. Vimos que uma progressiva evolução, multiplicada por brusco salto qualitativo, transfigurou as imagens iniciais do Diário, num conserto alegórico de alta hierarquia. A substância persecutória do chefete que o tiranizava, transmitida ao enfermeiro, cresce até fazê-lo chanceler e depois Grande Inquisidor, passando pelo intrigante príncipe de Polignac, esquecia-me de dizê-lo, presidente do Conselho francês de então. Sophie, que era um tanto Medji, virou a Mulher, insidiosa amante do Diabo. Os temas da xenofobia e do patriotismo confuso reapareceram, aqui e acolá, encontrando um repositório notável num "barbeiro que mora na rua da Ervilha", que tramaria espalhar o maometismo na Rússia, fé que já avassala a França... Todas essas imagens, e muitas outras, despojadas de sua lógica de concepção e conseqüência, como já se fez notar, soam completamente descabidas; não lhes alcançamos as razões, dentro do delírio convencional de Ivanovitch.

Todavia, o ridículo, como tal, a exterioridade invisível ao sujeito, mas que é tudo para ele, toda sua manifestação vangloriosa, este ainda reponta de quando em vez na narrativa do paciente internado. "Todo galo (bicho orgulhoso) tem uma Espanha escondida sob as asas", que é como se dissesse: "todos vós tendes na cabeça vaidosa sonhos como os meus". Em particular, porém, são os narizes que continuam representando o ridículo pomposo e os sonhos impossíveis. Todos têm narizes iguais, todos sonham suas 
loucuras, uns concretizam-nas na corte, se os meios lhes facultam, outros na Lua, em falta de lugar melhor. Nós, os aluados, os sonhadores sem condição, nós a quem trancafiam como lunáticos, nós temos uma Lua, pela qual devemos zelar. É notável e comovedor o episódio da sublevação dos doidos, quando Aksenti, aliás Fernando VIII, os convoca para defender a Lua, sobre a qual a Terra ameaça sentar-se. "A Lua é um globo tão pouco sólido que nela não pode viver gente de maneira alguma; quem vive lá são apenas os narizes. Nós não vemos os próprios narizes justamente porque eles se encontram todos na Lua." Sentando-se sobre ela, a Terra, a realidade prosaica, muito mais pesada e violenta, amassaria irremediavelmente nossos narizes, nossos sonhos de grandeza, frágeis e preciosos. E os loucos sobem pelas paredes para defender sua Lua em perigo. Não obstante, se aqui não há mais ridículo, mas delicada sugestão de liberdade poética, é simplesmente porque o ridículo encontra-se tematizado, é ele agora o objeto representado pela imagem - que, noutro contexto, seria o paradigma mesmo da irrisão. Nenhum de nós se enxerga, porque vivemos todos no mundo da lua. O ridículo fez a volta completa sobre si próprio, sublimou-se, encontrou sua vereda de redenção; ao assumir-se completamente, o ridículo alçou-se em drama.

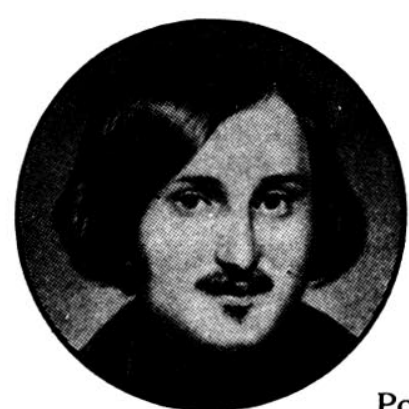

Nicolai Gógol (1809-1852)

sitório das intuições delirantes do conselheiro-titular, ele significa, entretanto, mais do que um simples caderno de anotações íntimas. O Diário possui certa espessura ontologica, por assim dizer, que medeia entre o campo do comentário e o campo do delírio. Gógol, já o pudemos constatar, cuida com esmero de posicionar o leitor segundo suas intenções. Como o Diário, ocupamos a fresta que se abre sutil entre o puro distanciamento, para o qual só se mostra uma superfície de imagens ridículas, e a participação dramática no delírio. Afinal, podemos crer por um instante na consistência da correspondência das cadelinhas, pensando tratar-se de convenção do gênero fantástico. $O$ fascinante, então, é que de fato se trata de uma convenção fantástica, mas ao mesmo tempo é já um produto delirante. Assim aliciados, partilhamos do engodo descomunal que o Autor nos impinge: eis aí o delírio, diz-nos ele, como é ridículo; e, no entanto, dele todos fazemos parte - "vocês, que não enxergam o próprio nariz, estão na mesma condição do burocrata e delirante Aksenti, só eu me elevo como o senhor dos títeres". E temos de admitir que alguma razão lhe assiste, ao artista que em sua arte se retira da mediocridade e sobe ao topo do delírio, que o ridiculariza, escondendo-lhe a montagem íntima (a lógica da concepção), para surgir vitorioso de si mesmo e do mundo acabrunhador.

A arte de ridicularizar o drama do delírio encarna-se, pois, na substância mediadora do Diário. O Diário é de um louco, mas constitui uma superfície normal de escrita, onde este vaza suas esquisitices. Destarte, é tão-somente testemunha, prova, demonstração. Tão normal, como o fotograma onde aparece um monstro, ou a fita gravada de uma sessão espiritualista, o Diário é só inocente papel. Contudo, ele comenta o absurdo burocrático, tem papel subversivo. Além disso, o Diário crê nas suas imagens, e delira, por conseguinte. Como distinguir tantas funções?

A série das datas registradas ilumina o problema. No primeiro tempo, que se estende de outubro a dezembro, ele cobre as açōes do que chamei preâmbulo e limiar. Durante esse período, o campo do quotidiano é assinalado pelas datas ordeiras e comuns: de 3 de outubro até 8 de dezembro. O ser do Diário então é o próprio campo do quotidiano, enfatizando o absurdo das imagens construídas por Aksenti. Estas destoam da ordem rigorosa e da meticulosidade do escriba. Quando se dá a revelação, porém, Aksenti, louco desde o início, não se houvera modificado, caso não se fizesse notar uma ruptura do campo prevalente, o da rotina perturbada, que cede passo ao do delírio. Nesse instante, o Diário mesmo se torna outro, encampa o delírio, arrastando-nos, com ele, para o novo campo. Arrastados, perderíamos talvez o senso do ridículo, caso a ruptura de campo não se grafasse com todas as letras no cimo da página: "ano 2000, 43 de abril". O Diário enlouqueceu diante de nossos olhos. Abril ainda é o quotidiano, o ano 2000 é o 
momento em que vigora essa realidade diversa e contrastante com abril, esta que estoura os limites da razão, como o número 43 estoura o limite cabível dos dias de um mês. Seguem-se datas parecidas: "86 de martoubro", “data nenhuma", "Dia 1", “Madrid, 30 de fevereiro", etc. É-nos comunicado, desse modo, que se passa a ação no tempo da loucura, em que se sustaram as regras da cronologia. É um comentário, portanto, um comentário acerca do campo que o Diário assumiu. $O$ último cabeçalho é o seguinte:

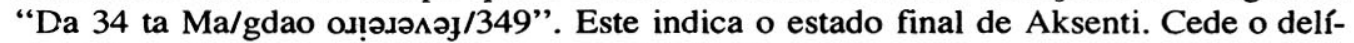
rio sistematizado diante dos argumentos do bastão, cede seu lugar a um estado de aparente consciência da moléstia, que, porém, outra coisa não é senão a intromissão e o acavalamento de campos, quer dizer, um estado de lucidez confusional. Doente da cura, Aksenti Ivanovitch enlouquece de vez.

$\mathrm{O}$ efeito de ridículo provém do desmembramento de uma unidade. $\mathrm{O}$ homem é um interior que se manifesta. Sua interioridade, a lógica de concepção que se chama também desejo, só se deve expor em seus produtos, as representações emocionais, as imagens. Quando o interior se deixa ver diretamente em sua atividade produtora, desperta asco. Asco é o sentimento correlato à visão das entranhas comuns a todos os homens, das do corpo e das da alma; pois, como a saliva, que ao se exteriorizar vira cuspo e já não cabe em nossa boca, nossa atividade interna deve guardar-se cautelosamente, caso contrário nauseia os demais; estes, vendo seu interior lá fora, não cabem em si de nojo, não podem mais engolir o espírito, profanado pela exposição no outro. $O$ delírio expõe a atividade interna do espírito, sob forma de distúrbios da razão, que em nada mais consistem senão na própria lógica do desejo, indevidamente manifesta. Já o ridículo é aquilo que sobra do homem quando a interioridade é cancelada, manifestação sem interior, puro motivo externo sem lógica que o justifique. Que seria, por conseguinte, a conjunção de asco e ridículo? Como nos mais sábios coquetéis, em que a combinação dos ingredientes faz desaparecer seus gostos particulares, asco mais ridículo, entranha e pele constituem o fascínio. Entende-se por fascínio a qualidade de máxima atração do objeto que promete, ao nosso descentramento e incompletude, a fusão perfeita no interior com a exterioridade. É que o projeto mais fundamental do desejo humano, naturalmente irrealizável, é o de bastar-se, fundindo corpo e veste, lógica de concepção e imagem representativa. Vem daí que a imagem do outro nos atraia tão fortemente e nos fascine: ele sou eu, invertidamente, da imagem ao interior; fundir-me com ele é completar um todo perdido, como na alegoria que o discurso de Aristófanes constrói, no Banquete. O fascínio que a loucura exerce sobre nós decorre, portanto, da dissecção e recomposição dos dois componentes - exterioridade ridícula e interioridade nauseante. Asco e ridículo compõem-se e decompõem-se incessantemente no delírio, formam uma figura humana e a desmancham logo a seguir, pondo em evidência a constituição mesma do fascínio, por efeito estroboscópico. Por ser essencialmente o delirante uma teoria viva do homem, é que nos seduz e nos repele alternadamente, às vezes num mesmo ambivalente movimento; reproduzir esse jogo ilusionista no texto literário é um desafio incontestável.

Como o enfrenta o Diário? De Aksenti Ivanovitch e de seu mundo medíocre, expõe sem piedade as imagens derrisórias; mas a atividade produtora ele esconde: suprimida a dimensão do asco, sobra o ridículo. Porém, ao se ir transformando, enlouquecendo ocultamente e sem perder a razão e a clareza, concentra em si mesmo o pólo amputado, a pura criatividade louca interior; com isso, conduz o leitor pela mão, primeiramente o fazendo rir do doido, depois a se condoer, para descobrir por fim que é ele mesmo o objeto de pena e ridículo. O Diário é, portanto, o interior que falta, ele detém e só aos bocados vai cedendo o complemento nauseante que, adicionado ao ridículo, compõe o homem e o fascina, dramaticamente. O Diário, por trás da superfície escrita de um diário, é puro fascínio complementar, atraindo e traindo o leitor, como o faria a análise com seu paciente, para que construa uma imagem, nela vaze todo o peso de suas emoções e descubra, no final, que a imagem é sempre a sua: todos nós narigudos. O Diário opera transferencialmente, este é seu delito e seu fascínio.

Seduzidos pelo Diário, sanidade delirante, mergulhamos nesse tempo sem calendário nem ordenação, mantidos na suspensão que nos faz rir do conselheiro-titular tornado rei de Espanha, ignorantes de o estarmos a esmagar com nosso assento tectônico, e ignorantes também de que o que se esmaga são nossos próprios sonhos, os narizes que não podemos ver. Por isso o drama é e deve permanecer ridículo: rindo, não nos reconhecemos, e podemos continuar a rir, a bandeiras despregadas. O ser reptilíneo do Diário operou essa ilusão. Mudando de estatuto ontológico, com gestos leves de prestidigitador, o Diário nos fascina, deixa-nos quedos e encantados, enquanto enfia alguma coisa tremenda e perigosa, uma loucura metastática, exatamente onde a não podemos ver: "Vocês já sabem que o rei de Argel tem um tumor exatamente debaixo do nariz?". 